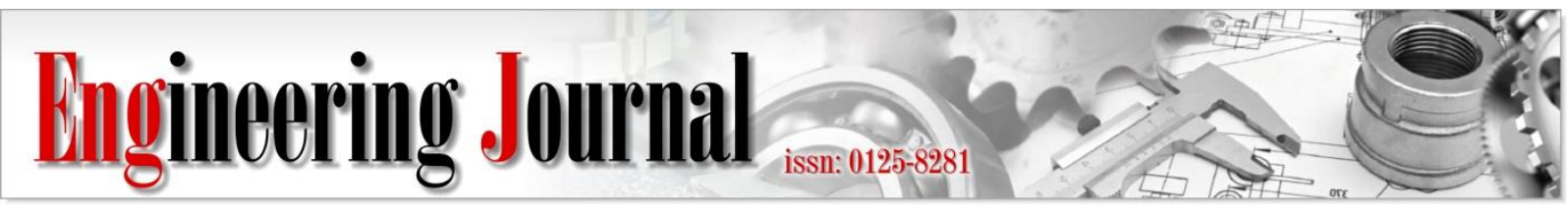

Article

\title{
Performance Evaluation of Construction Companies in Malaysia with Entropy-VIKOR Model
}

\author{
Lam Weng Siew ${ }^{1,2, a,{ }^{*}}$, Liew Kah Fai ${ }^{1,2, b}$, and Lam Weng Hoe ${ }^{1,2, c}$ \\ 1 Department of Physical and Mathematical Science, Faculty of Science, Universiti Tunku Abdul Rahman, \\ Kampar Campus, Jalan Universiti, Bandar Barat, 31900 Kampar, Perak, Malaysia \\ 2 Centre for Business and Management, Universiti Tunku Abdul Rahman, Kampar Campus, Jalan Universiti, \\ Bandar Barat, 31900 Kampar, Perak, Malaysia \\ E-mail: alamws@utar.edu.my (Corresponding author), bliewkf@utar.edu.my, cwhlam@utar.edu.my
}

\begin{abstract}
Construction industry is an important industry that has an enormous impact on the country's economic development. Nowadays, the government strives to encourage the construction industry to develop the advanced and modern infrastructure that related to health, transport, education, and housing. As a result, the Malaysian construction sector companies' financial performance is studied in this paper based on the crucial financial ratios. This paper aims to assess and compare the Malaysian construction sector companies' financial performance based on Entropy-VIKOR model. In this paper, the listed construction companies in Malaysia are investigated. The findings of this paper demonstrate that ZECON, DKLS, GADANG, TRIPLC, and MELATI are ranked as the top five construction companies based on the proposed model. The importance of this paper is to assess the construction companies' financial performance as well as identify the weights of the financial ratios in assessing the Malaysian construction sector companies' financial performance with the proposed Entropy-VIKOR model.
\end{abstract}

Keywords: Conceptual framework, performance assessment, VIKOR, multi-criteria decision making.

ENGINEERING JOURNAL Volume 25 Issue 1

Received 9 June 2020

Accepted 25 November 2020

Published 31 January 2021

Online at https://engj.org/

DOI:10.4186/ej.2021.25.1.297 


\section{Introduction}

Construction industry is an important industry that has an enormous impact on the economic development and national societies of any nation [1-5]. Malaysia has started to develop the construction industry since the significance of the construction sector has been realized. Construction industry plays an effective and significant role in providing great support to aggregate economy with other economy sectors [6]. In addition, it can also contribute in creating huge employment opportunities in the nation [7]. The development of the construction industry is directly proportional to the national economy [2]. As a result, the construction sector is important in providing a better life quality to the country that is crucial for the development of the country [7].

As a result, the Malaysian construction sector companies' financial performance is studied in this paper based on the crucial financial ratios. VIKOR is a multicriteria decision making model (MCDM) which assists the decision makers to make the selection and ranking from a number of alternatives in the presence of multiple contradictory and non-commensurable decision criteria [8-10]. The merit of the VIKOR model is to select alternatives with conflicting and inconsistent criteria [1115]. The compromise solution in the VIKOR model is a feasible solution that is the closest to the ideal $[16,17]$. Therefore, VIKOR model is proposed to assess the construction companies' financial performance in this study. Besides that, the entropy weight method focuses to identify the weights of the decision criteria, according to Shannon and Weaver [18].

Table 1. Proposed conceptual framework.
The application of Entropy-VIKOR model in various fields has been studied by the past researchers such as flood risk [19], environmental impacts [20], natural fiber reinforced brake friction material [21], Pelton turbine bucket [22], solar air flow channel [23] and environmental protection enterprises [24]. Since there is no comprehensive study on the construction companies in Malaysia, therefore this paper aims to bridge the research gap by assessing the Malaysian construction sector companies' financial performance with the proposed Entropy-VIKOR model. This paper aims to evaluate and compare the Malaysian construction sector companies' financial performance with EntropyVIKOR model. This paper will highlight the significance of research by considering important financial ratios in measuring the Malaysian construction sector companies' financial performance. The structure of this paper is organized as follows. The following section outlines the data and methodology used in detail along with procedural steps. Section 3 demonstrates the empirical results. Lastly, conclusions are drawn in the last section of this paper.

\section{Data and Methodology}

In this paper, the financial performance of the construction companies that listed in Malaysia stock market is analysed [25]. The data are gathered from the construction sector companies' financial annual report in year 2016. Table 1 shows the proposed conceptual framework to assess the Malaysian construction sector companies' financial performance with Entropy-VIKOR model.

\begin{tabular}{lc}
\hline Level & $\begin{array}{r}\text { Evaluation of construction sector companies' financial } \\
\text { performance }\end{array}$ \\
\hline Decision criteria & $\begin{array}{c}\text { Current ratio (CR), Debt to assets ratio (DAR), Debt to equity } \\
\text { ratio (DER), Earnings per share (EPS), Return on asset (ROA), } \\
\text { Return on equity (ROE) }\end{array}$ \\
\hline Decision alternatives & AZRB, BENALEC, BPURI, BREM, CRESBLD, DKLS, \\
& ECONBHD, EKOVEST, FAJAR, GADANG, GAMUDA, \\
& GBGAQRS, HOHUP, HSL, IJM, IKHMAS, KERJAYA, \\
KIMLUN, LEBTECH, MELATI, MERGE, MITRA, \\
MLGLOBAL, MUHIBAH, PESONA, PRTASCO, PSIPTEK, \\
PTARAS, SUNCON, SYCAL, TRC, TRIPLC, TSRCAP, \\
VIZIONE, WCHEHB, WCT, ZECON
\end{tabular}

According to past studies, the six important financial ratios such as CR, EPS, ROA, ROE, DAR, and DER are considered in this study [26-33]. In this study, CR, EPS, $\mathrm{ROA}$, and $\mathrm{ROE}$ are required to be maximized whereas the financial ratios that needed to be minimized are DAR and DER. 
The Entropy-VIKOR model consists of seven steps [3437].

Step 1: Calculate the weight of the decision criteria by using entropy weight method. Calculate the proportion " $p_{i j}$ " of alternative $m$ under criteria $n$.

$$
p_{i j}=\frac{x_{i j}}{\sum_{i=1}^{m} x_{i j}}, i=1,2, \ldots, m, j=1,2, \ldots, n
$$

Step 2: Determine the entropy " $e_{j}$ " of alternative $m$.

$$
e_{j}=-k \sum_{i=1}^{m} p_{i j} \cdot \ln \left(p_{i j}\right), j=1,2, \ldots, n
$$

where

$$
k=\frac{1}{\ln (m)}
$$

Step 3: Determine the entropy weight " $w_{j}$ " of alternative $m$.

$$
w_{j}=\frac{1-e_{j}}{\sum_{j=1}^{n}\left(1-e_{j}\right)}, j=1,2, \ldots, n
$$

Step 4: Identify the worst $f_{j}^{-}$and the best $f_{j}^{*}$ values for all the criterion functions, where $j=1, \ldots, n$.

Step 5: Compute $S_{i j}$ for $i=1, \ldots, m, j=1, \ldots, n$ where $n$ is the number of criteria and $m$ is the number of alternatives. $f_{i j}$ is refer to the score for alternative $i$ with criterion $j$.

$$
S_{i j}=\frac{w_{j}\left(f_{j}^{*}-f_{i j}\right)}{\left(f_{j}^{*}-f_{j}^{-}\right)}, i=1, \ldots, m, j=1, \ldots, n
$$

Step 6: Determine the $S_{i}, R_{i}$ and $Q_{i}$ values, $i=1, \ldots, m$. $v$ is referring to the maximum group utility's strategy weight. $v$ is equal to 0.5 .

$$
S_{i}=\sum_{j=1}^{n} \frac{w_{j}\left(f_{j}^{*}-f_{i j}\right)}{\left(f_{j}^{*}-f_{j}^{-}\right)}, i=1, \ldots, m
$$

$$
\begin{aligned}
R_{i} & =\max \frac{w_{j}\left(f_{j}^{*}-f_{i j}\right)}{\left(f_{j}{ }^{*}-f_{j}^{-}\right)}, i=1, \ldots, m \\
Q_{i} & =v \frac{\left(S_{i}-S^{*}\right)}{\left(S^{-}-S^{*}\right)}+(1-v) \frac{\left(R_{i}-R^{*}\right)}{\left(R^{-}-R^{*}\right)}
\end{aligned}
$$

where

$$
\begin{aligned}
& S^{-}=\max \left(S_{i}, i=1, \ldots, m\right) \\
& S^{*}=\min \left(S_{i}, i=1, \ldots, m\right) \\
& R^{-}=\max \left(R_{i}, i=1, \ldots, m\right) \\
& R^{*}=\min \left(R_{i}, i=1, \ldots, m\right)
\end{aligned}
$$

Step 7: Give the ranking of the alternatives based on the $Q$ values $[14,38]$. Select the best alternative by choosing the smallest $Q$ value.

\section{Empirical Results}

Figure 1 presents the weights of the decision criteria. As displayed in Fig. 1, the weights of the decision criteria have been determined by the entropy weight method. The EPS gives the highest weights of 0.2992 followed by ROE (0.2190), ROA (0.1972), DER (0.1886), CR (0.0604), and lastly DAR (0.0357). According to the weights of each financial ratio, CR and DAR are less important compared to EPS, ROE, ROA, and DER. On the other hand, it also indicates that EPS, ROE, ROA, and DER are the most crucial decision criteria in assessing the construction sector companies' financial performance in this study. Table 2 presents the best $f_{j}^{*}$ and the worst $f_{j}^{-}$values for all the financial ratios.

As shown in Table 2, the worst $f_{j}^{-}$and the best $f_{j}^{*}$ values for all the financial ratios are identified. As a result, the best $f_{j}^{*}$ values for CR, DAR, DER, EPS, ROA, and ROE are 4.7116, 0.1799, 0.2193, 0.7971, 16.3540, and 58.0629 , respectively. In contrast, the worst $f_{j}^{-}$values for CR, DAR, DER, EPS, ROA, and ROE are 0.1121, $0.8910,8.1781,0.0004,0.0508$ and 0.0962 , respectively. Table 3 presents the normalized decision matrix of this study, whereas Table 4 demonstrates the scores and ranking of the construction companies. 


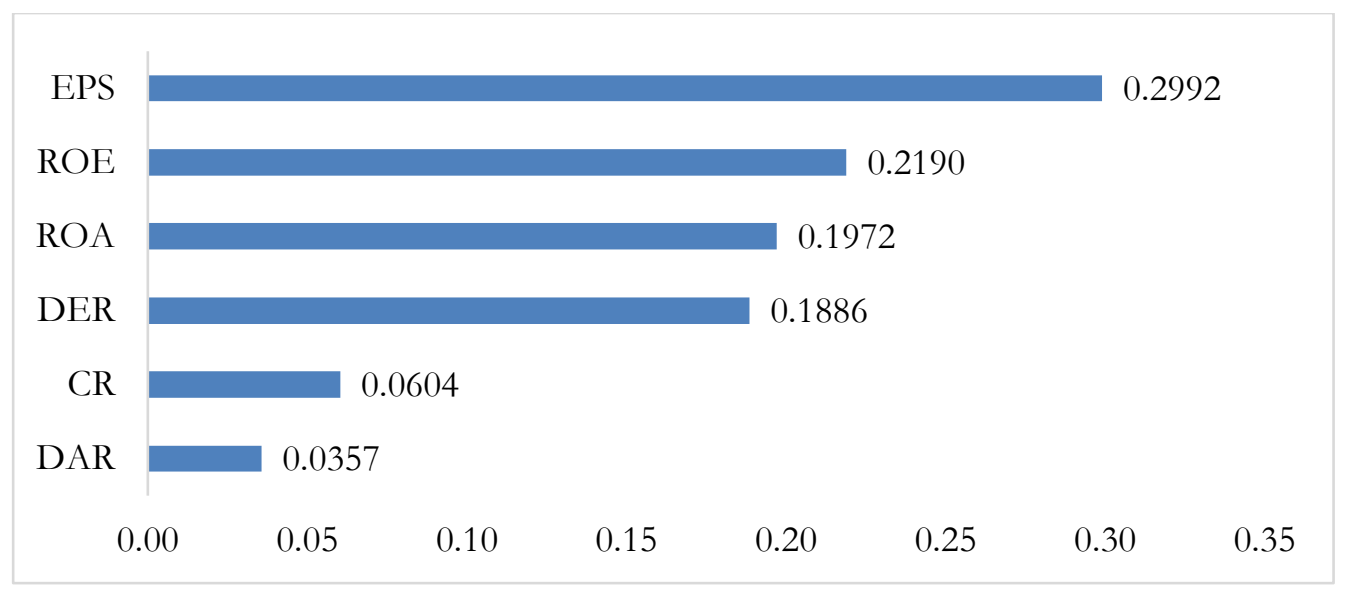

Fig. 1. Weights of the decision criteria.

Table 2. The worst $f_{j}^{-}$and the best $f_{j}^{*}$ values for all the financial ratios.

\begin{tabular}{lcc}
\hline \multicolumn{1}{c}{ Criteria } & Worst $\left(f_{j}^{-}\right)$ & Best $\left(f_{j}^{*}\right)$ \\
\hline CR & 0.1121 & 4.7116 \\
DAR & 0.8910 & 0.1799 \\
DER & 8.1781 & 0.2193 \\
EPS & 0.0004 & 0.7971 \\
ROA & 0.0508 & 16.3540 \\
ROE & 0.0962 & 58.0629 \\
\hline
\end{tabular}

Table 3. Normalized decision matrix.

\begin{tabular}{lcccccc}
\hline \multicolumn{1}{c}{ Company } & CR & DAR & DER & EPS & ROA & ROE \\
\hline AZRB & 0.0386 & 0.0357 & 0.1886 & 0.2802 & 0.1894 & 0.1954 \\
BENALEC & 0.0357 & 0.0181 & 0.0228 & 0.2910 & 0.1817 & 0.2084 \\
BPURI & 0.0475 & 0.0321 & 0.1030 & 0.2787 & 0.1883 & 0.2028 \\
BREM & 0.0199 & 0.0007 & 0.0005 & 0.2701 & 0.1572 & 0.2036 \\
CRESBLD & 0.0414 & 0.0256 & 0.0475 & 0.2675 & 0.1843 & 0.2058 \\
DKLS & 0.0412 & 0.0100 & 0.0093 & 0.0959 & 0.1047 & 0.1724 \\
ECONBHD & 0.0329 & 0.0111 & 0.0107 & 0.2519 & 0.0000 & 0.1161 \\
EKOVEST & 0.0377 & 0.0246 & 0.0429 & 0.2310 & 0.1506 & 0.1747 \\
FAJAR & 0.0355 & 0.0171 & 0.0206 & 0.2667 & 0.1263 & 0.1727 \\
GADANG & 0.0265 & 0.0191 & 0.0251 & 0.1618 & 0.1041 & 0.1526 \\
GAMUDA & 0.0307 & 0.0156 & 0.0176 & 0.1955 & 0.1407 & 0.1843 \\
GBGAQRS & 0.0421 & 0.0231 & 0.0371 & 0.2722 & 0.1628 & 0.1889 \\
HOHUP & 0.0399 & 0.0182 & 0.0230 & 0.2341 & 0.0826 & 0.1405 \\
HSL & 0.0153 & 0.0007 & 0.0005 & 0.2630 & 0.1196 & 0.1890 \\
IJM & 0.0228 & 0.0153 & 0.0170 & 0.1986 & 0.1440 & 0.1868 \\
IKHMAS & 0.0419 & 0.0195 & 0.0259 & 0.2919 & 0.1701 & 0.1994 \\
KERJAYA & 0.0357 & 0.0050 & 0.0040 & 0.2257 & 0.0836 & 0.1699 \\
KIMLUN & 0.0355 & 0.0137 & 0.0144 & 0.2002 & 0.0972 & 0.1620 \\
LEBTECH & 0.0192 & 0.0048 & 0.0038 & 0.2973 & 0.1927 & 0.2171 \\
MELATI & 0.0240 & 0.0044 & 0.0035 & 0.2049 & 0.0705 & 0.1650 \\
MERGE & 0.0429 & 0.0153 & 0.0171 & 0.2887 & 0.1785 & 0.2076 \\
MITRA & 0.0399 & 0.0161 & 0.0186 & 0.2313 & 0.0792 & 0.1451 \\
MLGLOBAL & 0.0485 & 0.0147 & 0.0160 & 0.2990 & 0.1972 & 0.2190 \\
MUHIBAH & 0.0475 & 0.0243 & 0.0415 & 0.1740 & 0.1503 & 0.1753 \\
PESONA & 0.0428 & 0.0205 & 0.0287 & 0.2878 & 0.1283 & 0.1666 \\
PRTASCO & 0.0460 & 0.0264 & 0.0519 & 0.2529 & 0.1521 & 0.1707 \\
PSIPTEK & 0.0366 & 0.0162 & 0.0188 & 0.2934 & 0.1816 & 0.2092 \\
PTARAS & 0.0000 & 0.0000 & 0.0000 & 0.2585 & 0.1446 & 0.1991 \\
\hline
\end{tabular}




\begin{tabular}{lcccccc}
\hline \multicolumn{1}{c}{ Company } & CR & DAR & DER & EPS & ROA & ROE \\
\hline SUNCON & 0.0604 & 0.0256 & 0.0478 & 0.2634 & 0.1042 & 0.1248 \\
SYCAL & 0.0355 & 0.0181 & 0.0228 & 0.2920 & 0.1838 & 0.2098 \\
TRC & 0.0419 & 0.0178 & 0.0220 & 0.2775 & 0.1570 & 0.1920 \\
TRIPLC & 0.0349 & 0.0260 & 0.0496 & 0.1636 & 0.1466 & 0.1663 \\
TSRCAP & 0.0453 & 0.0213 & 0.0312 & 0.2795 & 0.1725 & 0.1993 \\
VIZIONE & 0.0256 & 0.0083 & 0.0073 & 0.2992 & 0.1923 & 0.2167 \\
WCHEHB & 0.0141 & 0.0264 & 0.0517 & 0.2889 & 0.1836 & 0.2042 \\
WCT & 0.0431 & 0.0220 & 0.0333 & 0.2799 & 0.1871 & 0.2105 \\
ZECON & 0.0519 & 0.0310 & 0.0880 & 0.0000 & 0.0554 & 0.0000 \\
\hline
\end{tabular}

Table 4. Scores of the construction companies.

\begin{tabular}{lccc}
\hline \multicolumn{1}{c}{ Company } & Values $\boldsymbol{S}$ & Values $\boldsymbol{R}$ & Values $\boldsymbol{Q}$ \\
\hline AZRB & 0.9279 & 0.2802 & 0.9551 \\
BENALEC & 0.7577 & 0.2910 & 0.8593 \\
BPURI & 0.8524 & 0.2787 & 0.8977 \\
BREM & 0.6520 & 0.2701 & 0.7345 \\
CRESBLD & 0.7721 & 0.2675 & 0.8140 \\
DKLS & 0.4336 & 0.1724 & 0.3477 \\
ECONBHD & 0.4228 & 0.2519 & 0.5282 \\
EKOVEST & 0.6616 & 0.2310 & 0.6489 \\
FAJAR & 0.6389 & 0.2667 & 0.7171 \\
GADANG & 0.4894 & 0.1618 & 0.3624 \\
GAMUDA & 0.5845 & 0.1955 & 0.5099 \\
GBGAQRS & 0.7262 & 0.2722 & 0.7923 \\
HOHUP & 0.5384 & 0.2341 & 0.5685 \\
HSL & 0.5880 & 0.2630 & 0.6720 \\
IJM & 0.5845 & 0.1986 & 0.5171 \\
IKHMAS & 0.7488 & 0.2919 & 0.8552 \\
KERJAYA & 0.5239 & 0.2257 & 0.5381 \\
KIMLUN & 0.5230 & 0.2002 & 0.4771 \\
LEBTECH & 0.7348 & 0.2973 & 0.8578 \\
MELATI & 0.4723 & 0.2049 & 0.4522 \\
MERGE & 0.7503 & 0.2887 & 0.8486 \\
MITRA & 0.5302 & 0.2313 & 0.5560 \\
MLGLOBAL & 0.7943 & 0.2990 & 0.9043 \\
MUHIBAH & 0.6129 & 0.1753 & 0.4823 \\
PESONA & 0.6748 & 0.2878 & 0.7928 \\
PRTASCO & 0.7000 & 0.2529 & 0.7281 \\
PSIPTEK & 0.7557 & 0.2934 & 0.8635 \\
PTARAS & 0.6021 & 0.2585 & 0.6715 \\
SUNCON & 0.6261 & 0.2634 & 0.7003 \\
SYCAL & 0.7619 & 0.2920 & 0.8647 \\
TRC & 0.7083 & 0.2775 & 0.7923 \\
TRIPLC & 0.5870 & 0.1663 & 0.4427 \\
TSRCAP & 0.7492 & 0.2795 & 0.8261 \\
VIZIONE & 0.7493 & 0.2992 & 0.8727 \\
WCHEHB & 0.7690 & 0.2889 & 0.8625 \\
WCT & 0.7759 & 0.2799 & 0.8461 \\
ZECON & 0.2262 & 0.0880 & 0.0000 \\
\hline
\end{tabular}

As presented in step 6 , the $S^{*}, S^{-}, R^{*}$ and $R^{-}$have been determined in this study, $S^{*}=0.2262, S^{-}=0.9279, R^{*}=0.0880, R^{-}=0.2992$ and $v=0.5$. In this study, there are total of 37 construction companies evaluated based on important financial ratios such as CR, EPS, ROA, ROE, DAR, and DER.

Table 5 presents the performance ranking of construction companies. 
Table 5. Performance ranking of construction companies.

\begin{tabular}{|c|c|}
\hline Company & Ranking \\
\hline AZRB & 37 \\
\hline BENALEC & 30 \\
\hline BPURI & 35 \\
\hline BREM & 20 \\
\hline CRESBLD & 24 \\
\hline DKLS & 2 \\
\hline ECONBHD & 10 \\
\hline EKOVEST & 14 \\
\hline FAJAR & 18 \\
\hline GADANG & 3 \\
\hline GAMUDA & 8 \\
\hline GBGAQRS & 22 \\
\hline HOHUP & 13 \\
\hline HSL & 16 \\
\hline IJM & 9 \\
\hline IKHMAS & 28 \\
\hline KERJAYA & 11 \\
\hline KIMLUN & 6 \\
\hline LEBTECH & 29 \\
\hline MELATI & 5 \\
\hline MERGE & 27 \\
\hline MITRA & 12 \\
\hline MLGLOBAL & 36 \\
\hline MUHIBAH & 7 \\
\hline PESONA & 23 \\
\hline PRTASCO & 19 \\
\hline PSIPTEK & 32 \\
\hline PTARAS & 15 \\
\hline SUNCON & 17 \\
\hline SYCAL & 33 \\
\hline TRC & 21 \\
\hline TRIPLC & 4 \\
\hline TSRCAP & 25 \\
\hline VIZIONE & 34 \\
\hline WCHEHB & 31 \\
\hline WCT & 26 \\
\hline ZECON & 1 \\
\hline
\end{tabular}

Based on the proposed conceptual framework with Entropy-VIKOR model, the decision alternative with the lowest value of $\mathcal{Q}$ will be classified as the best alternative among the number of alternatives under consideration. Therefore, ZACON has been identified as the best construction company with $S, \mathrm{R}$, and $Q$ of $0.2262,0.0880$, and 0.0000 , respectively. On the other hand, AZRB is ranked as the lowest position based on $S, R$, and $\mathcal{Q}$ of $0.9279,0.2802$, and 0.9551 , respectively. In this study, ZECON gives the lowest value of $Q$, therefore $Z E C O N$ achieves the first ranking among the construction companies, followed by DKLS, GADANG, TRIPLC, MELATI, KIMLUN, MUHIBAH, GAMUDA, IJM, ECONBHD, KERJAYA, MITRA, HOHUP, EKOVEST, PTARAS, HSL, SUNCON, FAJAR, PRTASCO, BREM, TRC, GBGAQRS, PESONA, CRESBLD, TSRCAP, WCT, MERGE, IKHMAS, LEBTECH, BENALEC, WCHEHB, PSIPTEK, SYCAL,
VIZIONE, BPURI, MLGLOBAL and finally AZRB. In summary, ZECON has been identified as the best construction company in terms of financial performance among the listed construction companies in Malaysia. The contribution of this study is to provide a reference to those investors who are interested to make an investment in the field of construction.

\section{Conclusion}

In this study, the Entropy-VIKOR model is proposed in measuring the Malaysian construction sector companies' financial performance. This study demonstrates the successful implementation of EntropyVIKOR model. The results of this study show that ZECON, DKLS, GADANG, TRIPLC, and MELATI are the top five construction companies based on the proposed model. Moreover, the findings demonstrate 
that the most crucial financial ratio in assessing the financial performance of the construction companies is EPS, followed by ROE, ROA, DER, CR, and lastly DAR. The importance of this paper is to help determine the construction sector companies' financial performance as well as determine the weights of the decision criteria in measuring the Malaysian construction sector companies' financial performance with the proposed EntropyVIKOR model. For future study, the Entropy-VIKOR model can be extended and applied to other fields by considering the important attributes and criteria.

\section{Acknowledgement}

This study is supported by Universiti Tunku Abdul Rahman (UTAR), Malaysia.

\section{References}

[1] D. A. Turin, "The Construction Industry: Its Economic Significance and Its Role in Development," London: University College Environmental Research Group (UCERG), 1973.

[2] G. Ofori, "The Construction Industry: Aspects of Its Management and Economics," Singapore: Singapore University Press, 1990.

[3] G. Ofori, "Contemporary Issues in Construction in Developing Countries," Abingdon, UK: Spon Press, 2012.

[4] P. M. Hillebrandt, "Economic Theory and the Construction Industry," Basingstoke, UK: Macmillan, 2000.

[5] J. Lopes, "Construction in the economy and its role in socio-economic development," in. New Perspectives on Construction in Developing Countries, G. Ofori, Ed. Abingdon, UK: Spon Press, 2011.

[6] G. Ofori, "Nature of the construction industry, its needs and its development: A review of four decades of research," Journal of Construction in Developing Countries, vol. 20, no. 2, pp. 115-135, 2015.

[7] R. A. Khan, M. S. Liew, and Z. B. Ghazali, "Malaysian construction sector and Malaysia Vision 2020: Developed nation status," Procedia - Social and Behavioral Sciences, vol. 109, pp. 507-513, 2014.

[8] S. Opricovic, Multi-criteria Optimization of Civil Engineering Systems. Belgrade: Faculty of Civil Engineering, 1998.

[9] S. Opricovic and G. H. Tzeng, "Compromise solution by MCDM methods: A comparative analysis of VIKOR and TOPSIS," European Journal of Operational Research, vol. 156, no. 2, pp. 445-455, 2004.

[10] G. H. Tzeng, C. W. Lin, and S. Opricovic, "Multicriteria analysis of alternative-fuel buses for public transportation," Energy Policy, vol. 33, pp. 1373-1383, 2005.

[11] S. Opricovic and G. H. Tzeng, "Multicriteria planning of post-earthquake sustainable reconstruction," Computer-Aided Civil and
Infrastructure Engineering, vol. 17, no. 3, pp. 211-220, 2002.

[12] S. Opricovic and G. H. Tzeng, "Fuzzy multicriteria model for post-earthquake land-use planning," Natural Hazards Review, vol. 4, no. 2, pp. 59-64, 2003.

[13] G. H. Tzeng, C. W. Lin, and S. Opricovic, "Multicriteria analysis of alternative-fuel buses for public transportation," Energy Policy, vol. 33, pp. 1373-1383, 2005.

[14] S. Opricovic and G. H. Tzeng, "Extended VIKOR method in comparison with outranking methods," European Journal of Operational Research, vol. 178, no. 2, pp. 514-529, 2007.

[15] Y. P. Ou Yang, H. M. Shieh, and J. D. Leu, "A VIKOR-based multiple criteria decision method for improving information security risk," International Journal of Information Technology \& Decision Making, vol. 8, no. 2, pp. 267-287, 2009.

[16] P. L. Yu, "A class of solutions for group decision problems," Management Science, vol. 19, pp. 936-946, 1973.

[17] M. Zeleny, Multiple Criteria Decision Making. New York: Mc-Graw-Hill, 1982.

[18] C. E. Shannon and W. Weaver, "The Mathematical Theory of Communication," The University of Illinois Press, Urbana, 1947.

[19] A. Malekian and A. Azarnivand, "Application of integrated Shannon's Entropy and VIKOR techniques in prioritization of flood risk in the Shemshak Watershed, Iran," Water Resources Management, vol. 30, no. 1, pp. 409-425, 2016.

[20] J. Jovanovic, H. Shah, A. Vujovic, and Z. Krivokapic, "Application of MCDM methods in evaluation of environmental impacts," International Journal for Quality Research, vol. 8, no. 4, pp. 517-532, 2014.

[21] N. Kumar, T. Singh, R. S. Rajoria, and A. Patnaik, "Optimum design of natural fiber reinforced brake friction material using hybrid entropy-VIKOR approach," Advanced Science Letters, vol. 22, no. 11, pp. 3961-3964, 2016.

[22] R. Thakur, A. Kumar, R. Nadda, S. Khurana, and M. Sethi, "Experimental study and optimizing erosive wear rate parameters using a novel entropy vikor approach in a pelton turbine buckets," International Journal of Mechanical Engineering and Technology, vol. 8, no. 6, pp. 27-43, 2017.

[23] A. Sharma, R. Chauhan, T. Singh, A. Kumar, R. Kumar, A. Kumar, and M. Sethi, "Optimizing discrete $\mathrm{V}$ obstacle parameters using a novel Entropy-VIKOR approach in a solar air flow channel," Renewable Energy, vol. 106, pp. 310-320, 2017.

[24] W. Wang, and W. Lin, "Multi-criteria decision making model for evaluation of the growth of environmental protection enterprises," Ekoloji, vol. 27, no. 106, pp. 1887-1894, 2018.

[25] Bursa Malaysia. (n.d.). Company Announcements Bursa Malaysia Market. [Online]. Available: 
http://www.bursamalaysia.com/market/listedcompanies/companyannouncements $/ \# /$ ?category=all

[26] J. E. Price, M. D. Haddock, and H. R. Brock, College Accounting, 10th ed. New York: Macmillan/McGraw-Hill, 1993.

[27] O. Akguc, Financial Statement Analysis, 13th ed. Istanbul: Arayis Publication, 2010.

[28] H. A. Khrawish, "Determinants of commercial banks performance: Evidence from Jordan." International Research Journal of Finance and Economics, vol. 81, pp. 148-159, 2011.

[29] K. F. Liew, W. S. Lam, and W. H. Lam, "An empirical evaluation on the efficiency of the companies in Malaysia with Data Envelopment Analysis model," Advanced Science Letters, vol. 23, no. 9, pp. 8264-8267, 2017.

[30] W. H. Lam, M. A. Din, W. S. Lam and J. W. Chen, "Evaluation on the performance of suppliers in Malaysia with TOPSIS model," Journal of Fundamental and Applied Sciences, vol. 10, no. 6, pp. 406-415, 2018.

[31] W. H. Lam, W. S. Lam, and K. F. Liew, "Improvement on the efficiency of technology companies in Malaysia with Data Envelopment Analysis model," Lecture Notes in Computer Science, vol. 10645, pp. 19-30, 2017.

[32] W. S. Lam, K. F. Liew and W. H. Lam, "An optimal control on the efficiency of technology companies in Malaysia with Data Envelopment Analysis model," Journal of Telecommunication, Electronic and
Computer Engineering, vol. 10, no. 1, pp. 107-111, 2018.

[33] W. S. Lam, K. F. Liew, and W. H. Lam, "Investigation on the efficiency of financial companies in Malaysia with Data Envelopment Analysis model," Journal of Physics: Conference Series, vol. 995, no. 1, pp. 1-10, 2018.

[34] C. L. Chang and C. H. Hsu, "Multi-criteria analysis via the VIKOR method for prioritizing land-use restraint strategies in the Tseng-Wen reservoir watershed," Journal of Environmental Management, vol. 90, no. 11, pp. 3226-3230, 2009.

[35] A. H. Musfirah and A. G. Jaharah, "Magnesium and aluminum alloys in automotive industry," Journal of Applied Sciences Research, vol. 8, no. 9, pp. 4865-4875, 2012.

[36] S. Radhika, D. Sameer Kumar, and D. Swapna, "VIKOR method for multi criteria decision making in academic staff selection," Journal of Production Research and Management, vol. 3, no. 2, pp. 30-35, 2013.

[37] M. Ali, A. Yadav, M. Anis, and R. K. Shah, "Evaluation of hazardous waste management by using VIKOR: A case study of USA States," Modern Applied Science, vol. 11, no. 1, pp. 180-187, 2017.

[38] L. I. Tong, C. C. Chen, and C. H. Wang, "Optimization of multi-response processes using the VIKOR method," The International Journal of Advanced Manufacturing Technology, vol. 31, no. 11-12, pp. 1049-1057, 2007.

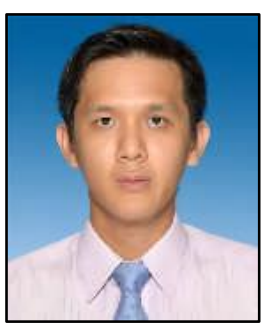

Lam Weng Siew was born in Perak, Malaysia. He received the B.Eng degree in mechanical engineering from the Universiti Sains Malaysia, Penang, Malaysia in 2004. He received the M.S. and Ph.D. degrees in mathematics from Universiti Kebangsaan Malaysia, Selangor, Malaysia.

He is an Assistant Professor at the Department of Physical and Mathematical Science, Faculty of Science, Universiti Tunku Abdul Rahman (UTAR), Perak, Malaysia. He is also a Head of Programme for the postgraduate programmes in Faculty of Science, UTAR. His research interests include optimization, data analytics, mathematical and statistical modeling, multi-criteria decision making, data envelopment analysis, logistics and transportation.

Ts. Dr. Lam was a recipient of the International Symposium on Research in Innovation and Sustainability Best Paper Award in 2019. Ts. Dr. Lam is a Professional Technologist (Malaysia Board of Technologists), HRDF Certified Trainer, SAS Certified Statistical Business Analyst, Certified Trainer on Machine Vision for Smart Manufacturing, Graduate Engineer (Board of Engineers Malaysia) and Associate Logistician (The Society of Logisticians, Malaysia). Ts. Dr. Lam is also a member of Malaysian Mathematical Sciences Society, Malaysian Institute of Statistics, Management Science/Operations Research Society of Malaysia as well as International Society of Development and Sustainability.

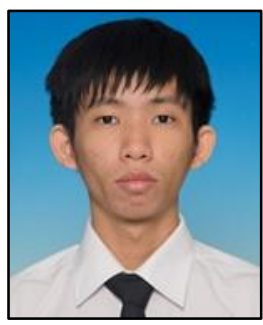

Liew Kah Fai was born in Perak, Malaysia. He received the B.S. in statistical computing and operations research as well as M.S. from Universiti Tunku Abdul Rahman (UTAR), Perak, Malaysia.

He is a lecturer at the Department of Physical and Mathematical Science, Faculty of Science, UTAR. His research interests include data envelopment analysis, multi-criteria decision making and statistical modeling. 
Mr. Liew was a recipient of the International Symposium on Research in Innovation and Sustainability Best Paper Award in 2019. Mr. Liew is a member of Malaysian Mathematical Sciences Society.

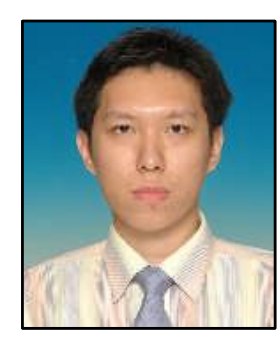

Lam Weng Hoe was born in Perak, Malaysia. He received the B.S. degree in actuarial science, M.S. and Ph.D. degrees in mathematics from Universiti Kebangsaan Malaysia, Selangor, Malaysia.

He is an Assistant Professor and Head of Department of Physical and Mathematical Science in Faculty of Science, Universiti Tunku Abdul Rahman (UTAR), Perak, Malaysia. His research interests include optimization, data analytics, mathematical and statistical modeling, multi-criteria decision making, data envelopment analysis, logistics and transportation.

Ts. Dr. Lam was a recipient of the International Symposium on Research in Innovation and Sustainability Best Paper Award in 2019. Ts. Dr. Lam is a Professional Technologist (Malaysia Board of Technologists) and Associate Logistician (The Society of Logisticians, Malaysia). Ts. Dr. Lam is also a member of Malaysian Mathematical Sciences Society, Malaysian Institute of Statistics, Management Science/Operations Research Society of Malaysia as well as International Society of Development and Sustainability. 